\title{
Comparative biological availability of manganese from extrinsically labelled milk diets using sucking rats as a model
}

\author{
BY M. HASSAN RAGHIB, WAI-YEE CHAN* AND OWEN M. RENNERT \\ Department of Pediatrics and Department of Biochemistry and Molecular Biology, \\ University of Oklahoma Health Sciences Center, Oklahoma City, OK 73190, USA
}

\section{(Received 2 January 1985 - Accepted 9 August 1985)}

1. Very little is known about the biological availability of manganese from human milk and other infant milk diets. To determine the relative $\mathrm{Mn}$ availability, and to examine whether the age and the duration of previous fasting affect Mn absorption, sucking rats were given human milk, bovine milk and infant formula (regular Similac; Ross Laboratories, Columbus, $\mathrm{OH}$ ) extrinsically labelled with ${ }^{54} \mathrm{Mn}$.

2. Milk diets were given by gastric intubation and the radioactivity of the carcass, liver and digestive tract was measured $3 \mathrm{~h}$ after feeding.

3. The concentration of endogenous $\mathrm{Mn}$ was lowest in human milk (7-10 $\mu \mathrm{g} / \mathrm{l})$ and highest in rat milk $(140-165 \mu \mathrm{g} / \mathrm{l})$. Increasing the non-radioactive total $\mathrm{Mn}$ concentrations of either human milk or bovine milk up to $150 \mu \mathrm{g} / \mathrm{l}$ did not affect the absorption of ${ }^{54} \mathrm{Mn}$ by $10-\mathrm{d}$-old rats.

4. No significant $(P>0.05)$ difference in ${ }^{54} \mathrm{Mn}$ absorption was found among the three milk diets (human milk, bovine milk, infant formula) in 8 - to 11 -d-old rats. However, significantly more $(P<0.05)^{54} \mathrm{Mn}$ was absorbed from human milk and infant formula than from bovine milk when $13-\mathrm{d}$-old rats were used.

5. ${ }^{54} \mathrm{Mn}$ radioactivity detected in carcasses of $8-, 9-, 10$ - and $11-\mathrm{d}$-old rats ranged from 25 to $27 \%$ of the dose from various milk diets. The activities of ${ }^{54} \mathrm{Mn}$ in the carcasses of 13 -d-old rats were 15,11 , and $16 \%$ of the dose from human milk, bovine milk and infant formula respectively.

6. The trend of ${ }^{54} \mathrm{Mn}$ incorporation into liver was similar to that of the carcass and over $60 \%$ of the absorbed ${ }^{54} \mathrm{Mn}$ was incorporated into the liver regardless of the type of milk used.

7. Absorption of ${ }^{54} \mathrm{Mn}$ from extrinsically labelled rat milk using 9 - or 10 -d-old sucking rats was similar to its absorption from infant formula.

8. The absorption of ${ }^{54} \mathrm{Mn}$ from the three milk diets decreased with age of the neonatal rats and ${ }^{54} \mathrm{Mn}$ absorption from human milk, bovine milk, infant formula as well as rat milk was affected similarly by duration of previous fasting.

Manganese is an integral part of pyruvate decarboxylase (EC 4.1.1.1) and mitochondrial superoxide dismutase $(E C$ 1.15.1.1). It activates a number of glycosyl transferases which are involved in polysaccharide and glycoprotein synthesis (Shaw, 1980; Hurley, 1982). Impaired growth, skeletal abnormalities, depressed reproductive function and ataxia in the newborn are common features of Mn deficiency in all species tested (Shaw, 1980; Hurley, 1982).

Dietary components may influence $\mathrm{Mn}$ absorption. The high $\mathrm{Mn}$ requirement in poultry may reflect the inhibition of $\mathrm{Mn}$ absorption by high levels of calcium and phosphorus in the poultry diet (Forbes \& Erdman, 1983). In rats, low levels of $\mathrm{Ca}$ and iron in the diet are associated with increased Mn absorption (Forbes \& Erdman, 1983).

The Mn concentration of human milk is much lower than that found in bovine milk and infant formulas (Committee on Nutrition, 1979; Barness, 1981). However, chemical analysis may not reflect the biologically effective levels of $\mathrm{Mn}$ in milk diets. Previous studies in our laboratory using everted small intestine from adult rats demonstrated a difference in the availability of Mn from human milk, bovine milk and infant formulas (Chan et al. 1984). Using extrinsic labelling, the availability of Fe from human milk was found to be five to ten times greater than that from infant formulas even though the latter contained 
significantly more Fe (McMillan et al. 1977; Saarinen et al. 1977). To eliminate the possibility of interference with absorption of the nutrients under study by the gut contents, a fasting time of 12-24 h has been reported for adult rats (Jackson et al. 1981; Garcia-Aranda et al. 1983). A decrease in zinc (Shah, 1981), ${ }^{95} \mathrm{Nb}$ (Mraz \& Eisele, 1977), ${ }^{115} \mathrm{Cd}$ (Sasser \& Jarboe, 1977) and lead, Cd and mercury (Kostial et al. 1979) absorption has been reported in older rats compared with young ones.

Infant formulas are supplemented with $\mathrm{Mn}$ and other trace elements in the form of inorganic salts which may have different availabilities from those of the trace elements found naturally in human and bovine milk. The purpose of the present study was to evaluate the availability of $\mathrm{Mn}$ in various milk diets using sucking rats as a model and to determine whether any species specificity for $\mathrm{Mn}$ absorption exists by comparing rat milk with other types of milk. Furthermore, the effects of age and previous fasting on ${ }^{54} \mathrm{Mn}$ absorption by sucking rats were investigated.

\section{MATERIALS AND METHODS}

\section{Animals and the experimental design}

Sucking Sprague-Dawley rats (8-to 13-d-old) were separated from their mothers $14 \mathrm{~h}$ before the administration of milk. The mothers were given regular chow (Wayne Rodent Blox 8604-00, Wayne Animal Research Diet, Chicago, IL). Fresh human milk (mature milk from volunteers), and raw bovine milk were obtained locally. An infant formula (regular Similac: Ross Laboratories, Columbus, $\mathrm{OH}$ ) was used directly from the bottle. Following the same general procedure, absorption of ${ }^{54} \mathrm{Mn}$ from rat milk was compared with its absorption from infant formula in a separate experiment. Fresh rat milk was obtained from female rats, $8-12 \mathrm{~d}$ after parturition, as follows. Pups were removed from their mothers at least $4 \mathrm{~h}$ before milking, allowing the milk to accumulate in the glands, then the female rats were injected intraperitoneally with $30 \mathrm{mg}$ pentobarbital sodium $/ \mathrm{kg}$ body-weight. After the animals became unconscious (10-20 $\mathrm{min}$ ) they were injected subcutaneously with 2 i.u. oxytocin and milked immediately, using a home-made milking apparatus similar to that used by previous investigators (Feller \& Boretos, 1967; Nagasawa, 1979; Hoffman et al. 1982). The milking apparatus consisted of a vacuum pump, polyethylene tubing, rubber stopper to which two 14-gauge catheter needles (Becton-Dickinson, Rutherford, NJ) were inserted, a glass tube, and a white pipette tip (Bio-Rad, Richmond, CA). A small portion of the narrow end of the pipette tip was cut off and made into a teat cup by filling the inner opening with silicone rubber cement into which the entire nipple of one mammary gland was drawn at any one time. Each milk sample was incubated for $2 \mathrm{~h}$ with carrier-free ${ }^{54} \mathrm{MnCl}_{2}$ (New England Nuclear, Boston MA) in a final concentration of $4-5 \mu \mathrm{Ci}^{54} \mathrm{Mn} / \mathrm{ml}$ milk. This method had been shown to label endogenous Mn-binding ligands successfully (Chan et al. 1982). To avoid milk coagulation, radioactive $\mathrm{Mn}$ solution in $0.5 \mathrm{M}$-hydrochloric acid was buffered with an equal volume of $0 \cdot 1 \mathrm{M}$-sodium bicarbonate, $\mathrm{pH} 7 \cdot 4$, before adding to the milk. Only litters with eight or more pups were used and a minimum of two pups were allocated to each treatment at any given feeding experiment. Each experiment was repeated at least three times. Each pup was weighed before stomach intubation of $0.1 \mathrm{ml}$ milk by a 24-gauge ball-tipped needle (Popper and Sons Inc., New York) connected to a $1 \mathrm{ml}$ tuberculin syringe (Jelco Laboratories, Rariton, NJ). Live animals were counted for $1 \mathrm{~min}$ in a gamma counter soon after feeding. If the size of the pups would not allow a 1 min count of the animals, the total ${ }^{54} \mathrm{Mn}$ fed was calculated from previously-counted milk samples (100 $\mu \mathrm{l}$ of each milk sample). At $3 \mathrm{~h}$ after feeding, the pups were anesthetized with diethyl ether and killed. The entire digestive tract was removed from the carcass and the radioactivity of stomach and intestine was determined separately. After the radioactivity in the carcass was 
determined, the liver was removed, washed, blotted dry, weighed and the radioactivity measured.

\section{Analytical methods}

Endogenous milk Mn was measured, in triplicate, either directly or after dilution with deionized water by a Perkin-Elmer atomic absorption spectrophotometer (model 703, Perkin-Elmer; Norwalk, CT) equipped with a graphite furnace (HGA 500). A $10 \mu \mathrm{l}$ portion of sample was injected into the pyrolytically coated graphite furnace by automatic sampler (model A5-1). Milk and tissue samples containing ${ }^{54} \mathrm{Mn}$ were counted by a deep-well gamma counter (model 8000, Beckman; Palo Alto, CA). Due to the geometrical difference of a whole carcass and the liver in the deep-well, the carcass counts of the small and large sucking rats were multiplied by correction factors determined experimentally.

\section{Statistical analysis}

Differences between groups in the dependent variables $\left({ }^{54} \mathrm{Mn}\right.$ count of carcass, liver and digestive tract or stomach) were tested for significance by analysis of variance (SAS User's Guide 1977 edition, SAS Institute, Raleigh, NC). In one experiment the independent variables for the tests were the period after feeding (four levels, i.e. 1, 2, 3 and $4 \mathrm{~h}$ ), the type of milk diets (three levels, namely human milk, bovine milk and infant formula) and the age of the sucking rats (five levels, i.e. 8-, 9-, 10-, 11- and 13-d-old). In another study, independent variables were diet (two levels, rat milk and infant formula) and duration of previous fasting (four levels, 10,12, 14 and $18 \mathrm{~h}$ ). The results of three or more experiments were combined and the differences among the mean values of the treatments were subjected to analysis of variance allowing for an unequal number of animals in each treatment group. All dependent variables were consistent with respect to the presence or absence of the missing values. The probability of occurrence by chance of $P<0.05$ was accepted as significant.

RESULTS

The endogenous $\mathrm{Mn}$ concentrations of human milk, bovine milk, infant formula and rat milk used in the present study were 8 (SD 3), 30 (SD 5), 73 (SD 4) and 148 (SD 18) $\mu \mathrm{g} / 1$ respectively. In order to find out if higher endogenous $\mathrm{Mn}$ concentrations of some diets may affect the absorption of ${ }^{54} \mathrm{Mn}, \mathrm{MnCl}_{2}$ was added to either labelled human milk or bovine milk to increase the total non-radioactive $\mathrm{Mn}$ concentrations up to 70 or $150 \mu \mathrm{g} / \mathrm{l}$. The results shown in Table 1 indicate that added $\mathrm{Mn}$ in bovine milk had little or no effect on the absorption of ${ }^{54} \mathrm{Mn}$ by the 10 -d-old rats $3 \mathrm{~h}$ after feeding. Similar results were obtained when human-milk Mn was increased up to 70 or $150 \mu \mathrm{g} / \mathrm{l}$.

The absorption of ${ }^{54} \mathrm{Mn}$, over a $3 \mathrm{~h}$ period of assimilation, was similar in 9-d-old rats regardless of whether human milk, bovine milk or infant formula was given (Table 2). Although ${ }^{54} \mathrm{Mn}$ absorption from human milk and infant formula was higher compared with rats given bovine milk, no significant $(P>0.05)$ difference existed among the three milk diets. Similar results were obtained when $8-, 10$ - and 11-d-old sucking rats were used. Total ${ }^{54} \mathrm{Mn}$ absorption appeared to decrease with age but this was not significant $(P>0.05)$ in 8- to 11-d-old rats.

The values in Table 2 show that the recovery of ${ }^{54} \mathrm{Mn}$ was $99-100 \%$ when the relative amounts of ${ }^{54} \mathrm{Mn}$ in the carcass and the digestive tract were added together. This means that essentially no ${ }^{54} \mathrm{Mn}$ was lost either through the urine or faeces during the $3 \mathrm{~h}$ assimilation period. Further studies indicated that the recovery of ${ }^{54} \mathrm{Mn}$ was approximately $99-100 \%$ after $4 \mathrm{~h}$ of assimilation.

Total ${ }^{54} \mathrm{Mn}$ absorption did not increase significantly when the assimilation time was 
Table 1. Effect of added manganese on absorption of ${ }^{54} \mathrm{Mn}$-labelled bovine milk by 10-d-old sucking rats $3 \mathrm{~h}$ after gastric intubation

(Mean values and standard deviations for no. of pups indicated)

\begin{tabular}{|c|c|c|c|c|c|c|c|}
\hline \multirow{3}{*}{$\begin{array}{l}\text { Total non-radioactive } \\
\text { milk } \operatorname{Mn}(\mu \mathrm{g} / \mathrm{l})^{*}\end{array}$} & \multirow[b]{3}{*}{$n$} & & & \multicolumn{4}{|c|}{${ }^{54} \mathrm{Mn}$ count $(\%$ of dose $)$} \\
\hline & & \multicolumn{2}{|c|}{ Body wt (g) } & \multicolumn{2}{|c|}{ Carcass } & \multicolumn{2}{|c|}{ Liver } \\
\hline & & Mean & SD & Mean & $\mathrm{SD}$ & Mean & SD \\
\hline 30 & 6 & $16 \cdot 1$ & $3 \cdot 5$ & $31 \cdot 0$ & $4 \cdot 4$ & $20 \cdot 8$ & 3.0 \\
\hline 70 & 6 & $17 \cdot 3$ & $4 \cdot 4$ & $33 \cdot 3$ & $2 \cdot 9$ & $22 \cdot 0$ & $2 \cdot 3$ \\
\hline 150 & 7 & $17 \cdot 7$ & 3.8 & $31 \cdot 8$ & $4 \cdot 4$ & $22 \cdot 1$ & 3.0 \\
\hline
\end{tabular}

* Endogenous bovine milk Mn concentration was $30 \mu \mathrm{g} / \mathrm{l}$ which was increased to 70 and $150 \mu \mathrm{g} / 1$ by adding manganese chloride solution.

Table 2. Absorption of ${ }^{54} \mathrm{Mn}$ from human milk, bovine milk and infant formula by 9-d-old sucking rats $3 h$ after gastric intubation

(Mean values and standard deviations for no. of animals indicated; results of five different feeding experiments (pups from five mothers) were pooled for each of the three milk diets)

\begin{tabular}{|c|c|c|c|c|c|c|c|}
\hline \multirow[b]{3}{*}{ Treatment } & \multirow[b]{3}{*}{$n$} & \multicolumn{6}{|c|}{${ }^{54} \mathrm{Mn}(\%$ of dose) } \\
\hline & & \multicolumn{2}{|c|}{ Body wt (g) } & \multicolumn{2}{|c|}{ Carcass* } & \multicolumn{2}{|c|}{$\begin{array}{c}\text { Digestive } \\
\text { tract } \dagger\end{array}$} \\
\hline & & Mean & SD & Mean & SD & Mean & SD \\
\hline Human milk & 13 & 13 & 2 & 31 & 7 & 69 & 7 \\
\hline Bovine milk & 12 & 13 & 2 & 28 & 6 & 71 & 9 \\
\hline Infant formula & 13 & 12 & 1 & 31 & 7 & 69 & 8 \\
\hline
\end{tabular}

No significant difference in ${ }^{54} \mathrm{Mn}$ absorption existed among the three diets $(P<0.05)$.

* Carcass values are for the whole body including liver minus digestive tract.

$\dagger$ Digestive tract values are for stomach, small and large intestines.

extended to $4 \mathrm{~h}$ (Table 3). In fact the rate of ${ }^{54} \mathrm{Mn}$ absorption (calculated as $\%$ of dose $/ \mathrm{h}$ ) from human milk, bovine milk and infant formula began to diminish from a combined average value of $8.6(\mathrm{SD} 1.6) \%$ at $3 \mathrm{~h}$ to a combined average value of $6.8(\mathrm{SD} 1.1) \%$ after $4 \mathrm{~h}$ of assimilation (Table 4). The decrease in ${ }^{54} \mathrm{Mn}$ absorption with time of assimilation was further noticed as the overall rates of ${ }^{54} \mathrm{Mn}$ absorption from the three types of milk diet were approximately $4.1 \%$ and $2.7 \%$ of the dose at the end of 12 and $24 \mathrm{~h}$ of assimilation respectively. Thus, $3 \mathrm{~h}$ was determined to be the optimal assimilation period in the present study.

The main site of Mn absorption was in the small intestine rather than the stomach. At the end of $1 \mathrm{~h}$, up to $20 \%$ of the ingested milk was still present in the stomach as measured by stomach ${ }^{54} \mathrm{Mn}$ content. The presence of milk in the stomach could also be observed visually at the time of death, but this gradually decreased to less than $10 \% 3 \mathrm{~h}$ after milk administration. ${ }^{54} \mathrm{Mn}$ absorption was observed to be inversely proportional to the amount of radioactivity remaining in the stomach at various assimilation times (Table 3 ). No significant difference $(P>0.05)$ in stomach ${ }^{54} \mathrm{Mn}$ activity was found between 3 and $4 \mathrm{~h}$ of 
Table 3. Relation of stomach milk ${ }^{54} \mathrm{Mn}$ content to its absorption by 8 -and 11-d-old rats at various times after intubation

(Mean values and standard deviations for no. of animals indicated; the results of three individual feeding experiments were combined for each of the three milk diets at both 8 and $11 \mathrm{~d}$ of age)

\begin{tabular}{|c|c|c|c|c|c|c|c|c|c|c|c|c|c|}
\hline \multirow[b]{3}{*}{ Treatment } & \multirow{3}{*}{$\begin{array}{l}\text { Period of } \\
\text { assimilation } \\
\text { (h) }\end{array}$} & \multicolumn{7}{|c|}{ 8-d-old } & \multicolumn{5}{|c|}{ 11-d-old } \\
\hline & & \multirow[b]{2}{*}{$n$} & \multicolumn{2}{|c|}{$\begin{array}{c}\text { Absorbed } \\
{ }^{54} \mathrm{Mn} \\
(\% \text { of } \\
\text { dose })\end{array}$} & \multicolumn{2}{|c|}{$\begin{array}{l}\text { Liver } \\
{ }^{54} \mathrm{Mn} \\
(\% \text { of } \\
\text { dose })\end{array}$} & \multicolumn{2}{|c|}{$\begin{array}{c}\text { Stomach } \\
{ }^{54} \mathrm{Mn}^{* \dagger} \\
(\% \text { of } \\
\text { dose) }\end{array}$} & \multirow[b]{2}{*}{$n$} & \multicolumn{2}{|c|}{$\begin{array}{c}\text { Absorbed } \\
{ }^{54} \mathrm{Mn} \\
(\% \text { of } \\
\text { dose })\end{array}$} & \multicolumn{2}{|c|}{$\begin{array}{c}\text { Stomach } \\
{ }^{54} \mathrm{Mn}^{* \dagger} \\
(\% \text { of } \\
\text { dose) }\end{array}$} \\
\hline & & & Mean & SD & Mean & SD & Mean & SD & & Mean & SD & Mean & SD \\
\hline \multirow[t]{4}{*}{ Human milk } & 1 & 8 & 12 & 2 & 9 & 2 & 18 & 11 & 10 & 10 & 4 & 20 & 16 \\
\hline & 2 & 10 & 18 & 5 & 13 & 4 & 15 & 6 & 12 & 16 & 3 & 18 & 10 \\
\hline & 3 & 8 & 30 & 5 & 23 & 5 & 9 & 3 & 8 & 21 & 5 & 9 & 7 \\
\hline & 4 & 8 & 32 & 7 & 23 & 6 & 6 & 3 & 10 & 24 & 2 & 8 & 6 \\
\hline \multirow[t]{4}{*}{ Bovine milk } & 1 & 8 & 9 & 3 & 7 & 2 & 33 & 14 & 9 & 9 & 2 & 17 & 10 \\
\hline & 2 & 8 & 16 & 4 & 13 & 4 & 19 & 8 & 10 & 16 & 2 & 11 & 5 \\
\hline & 3 & 8 & 27 & 5 & 24 & 4 & 9 & 6 & 8 & 21 & 4 & 10 & 5 \\
\hline & 4 & 7 & 28 & 4 & 23 & 3 & 9 & 4 & 10 & 28 & 2 & 8 & 2 \\
\hline \multirow[t]{4}{*}{ Infant formula } & 1 & 8 & 12 & 2 & 9 & 3 & 25 & 12 & 11 & 12 & 3 & 20 & 8 \\
\hline & 2 & 8 & 20 & 4 & 14 & 3 & 16 & 7 & 13 & 16 & 4 & 12 & 5 \\
\hline & 3 & 8 & 30 & 5 & 24 & 5 & 7 & 2 & 8 & 27 & 6 & 7 & 2 \\
\hline & 4 & 7 & 32 & 4 & 26 & 2 & 7 & 2 & 10 & 28 & 2 & 7 & 3 \\
\hline
\end{tabular}

* Significant $(P<0.05)$ difference in stomach ${ }^{54} \mathrm{Mn}$ activity existed between $2 \mathrm{~h}$ or less and $3 \mathrm{~h}$ or more of assimilation time.

$\dagger$ No significant difference in stomach ${ }^{54} \mathrm{Mn}$ activity existed between 8 - and 11 -d-old rats at the corresponding periods of $1,2,3$ or $4 \mathrm{~h}$ of assimilation.

Table 4. Rate of ${ }^{54} \mathrm{Mn}$ absorption by 8 - and 11-d-old rats at various times after feeding of milk diets

(Mean values and standard deviations for no. of pups indicated; the results of three individual experiments were pooled, a minimum of two pups per pooled treatment in each experiment)

\begin{tabular}{|c|c|c|c|c|c|c|c|}
\hline \multirow[b]{3}{*}{ Treatment } & \multirow{3}{*}{$\begin{array}{l}\text { Period of } \\
\text { assimilation } \\
\text { (h) }\end{array}$} & \multicolumn{6}{|c|}{${ }^{54} \mathrm{Mn}$ absorbed* $(\%$ of dose $/ \mathrm{h})$} \\
\hline & & \multicolumn{3}{|c|}{ 8-d-old } & \multicolumn{3}{|c|}{ 11-d-old } \\
\hline & & $n$ & Mean & SD & $n$ & Mean & SD \\
\hline Human milk & $\begin{array}{l}1 \\
2 \\
3 \\
4\end{array}$ & $\begin{array}{r}8 \\
10 \\
8 \\
8\end{array}$ & $\begin{array}{r}12 \\
9 \\
10 \\
8\end{array}$ & $\begin{array}{l}2 \\
3 \\
2 \\
1\end{array}$ & $\begin{array}{r}10 \\
12 \\
8 \\
10\end{array}$ & $\begin{array}{r}11 \\
8 \\
7 \\
6\end{array}$ & $\begin{array}{l}4 \\
3 \\
2 \\
1\end{array}$ \\
\hline Bovine milk & $\begin{array}{l}1 \\
2 \\
3 \\
4\end{array}$ & $\begin{array}{l}8 \\
8 \\
8 \\
7\end{array}$ & $\begin{array}{l}9 \\
8 \\
9 \\
7\end{array}$ & $\begin{array}{l}3 \\
2 \\
2 \\
1\end{array}$ & $\begin{array}{r}9 \\
10 \\
8 \\
10\end{array}$ & $\begin{array}{l}9 \\
8 \\
7 \\
5\end{array}$ & $\begin{array}{l}2 \\
1 \\
2 \\
1\end{array}$ \\
\hline Infant formula & $\begin{array}{l}1 \\
2 \\
3 \\
4\end{array}$ & $\begin{array}{l}8 \\
8 \\
8 \\
7\end{array}$ & $\begin{array}{r}12 \\
10 \\
10 \\
8\end{array}$ & $\begin{array}{l}2 \\
2 \\
2 \\
1\end{array}$ & $\begin{array}{r}11 \\
13 \\
8 \\
10\end{array}$ & $\begin{array}{r}12 \\
8 \\
9 \\
7\end{array}$ & $\begin{array}{l}3 \\
2 \\
3 \\
1\end{array}$ \\
\hline
\end{tabular}

* Total amount of ${ }^{54} \mathrm{Mn}$ absorbed was divided by assimilation time and the values expressed as $\%$ of dose $/ \mathrm{h}$. 
Table 5. Incorporation of ${ }^{54} \mathrm{Mn}$ into the liver of 9-d-old sucking rats from human milk, bovine milk, and infant formula 3 h after gastric intubation

(Mean values and standard deviations for no. of animals indicated; the results of five individual feeding experiments were pooled for each of the three milk diets)

\begin{tabular}{|c|c|c|c|c|c|c|c|}
\hline \multirow[b]{3}{*}{ Treatment } & \multirow[b]{3}{*}{$n$} & \multicolumn{4}{|c|}{${ }^{54} \mathrm{Mn}(\%$ of dose $)$} & \multirow{2}{*}{\multicolumn{2}{|c|}{$\begin{array}{c}{ }^{54} \mathrm{Mn}(\% \text { of } \\
\left.\text { carcass }{ }^{54} \mathrm{Mn}\right)\end{array}$}} \\
\hline & & \multicolumn{2}{|c|}{ Whole liver } & \multicolumn{2}{|c|}{$\operatorname{Liver}(/ \mathrm{g})$} & & \\
\hline & & Mean & SD & Mean & SD & Mean & SD \\
\hline Human milk & 13 & 19 & 6 & 46 & 12 & 65 & 3 \\
\hline Bovine milk & 12 & 19 & 7 & 42 & 12 & 66 & 7 \\
\hline Infant formula & 13 & 19 & 4 & 43 & 12 & 64 & 6 \\
\hline
\end{tabular}

Incorporation of ${ }^{54} \mathrm{Mn}$ into the liver was not significantly different $(P>0.05)$ among the three milk diets.

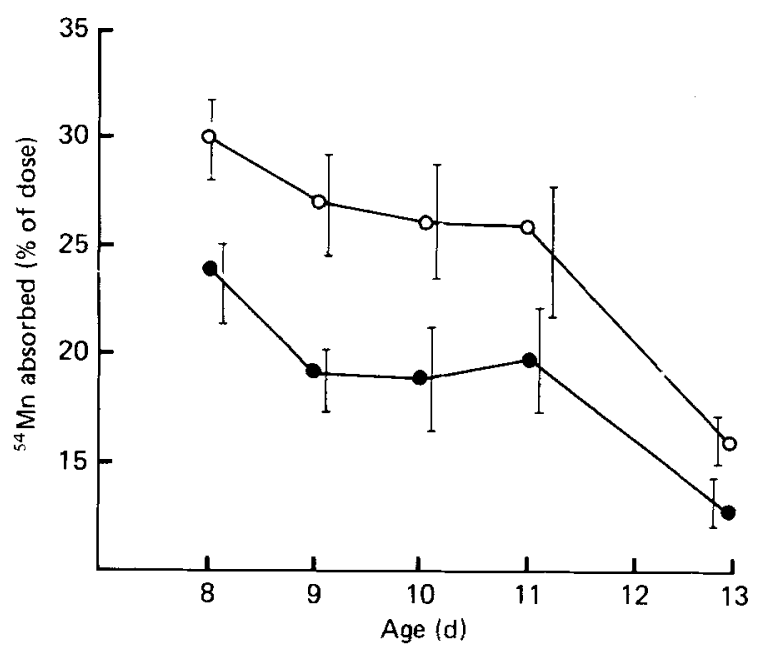

Fig. 1. Effect of age on ${ }^{54} \mathrm{Mn}$ absorption from infant formula $3 \mathrm{~h}$ after gastric intubation. There were ten, thirteen, twenty-four, eight and sixteen pups in the 8-, 9-, 10-, 11- and 13-d-old groups respectively. The average body-weights of pups were 12.0 (SD 1.4), 12.6 (SD 1.7), 15.6 (SD 3.4), 18.8 (SD 2.9) and $21 \cdot 7$ (sD 3.5) g for 8-, 9-, 10-, 11 - and 13-d-old rats respectively. Carcass ${ }^{54} \mathrm{Mn}(\mathrm{O}-\mathrm{O})$; liver ${ }^{54} \mathrm{Mn}(\mathrm{O}-\mathrm{O})$. Points are mean values and standard deviations represented by vertical bars.

assimilation. However, a significantly higher $(P<0.01)$ amount of ${ }^{54} \mathrm{Mn}$ was present in the stomach after 1 or $2 \mathrm{~h}$ of feeding than after 3 or $4 \mathrm{~h}$. One of the reasons for measuring stomach ${ }^{54} \mathrm{Mn}$ radioactivity was to determine whether any difference existed in the passage of various milk diets from the stomach into the intestine and if the passage of the milk was affected by the age of the pups. As shown in Table 3, no difference in passage of milk from the stomach was observed, either among the three milk diets or between 8- and 11-d-old rats.

The incorporation of ${ }^{54} \mathrm{Mn}$ into the liver of 9-d-old rats followed the same trend as that of the carcass minus digestive tract (Table 5). Most (over $60 \%$ ) of the carcass ${ }^{54} \mathrm{Mn}$ was concentrated in the liver. No difference was observed among the three dietary groups regardless of whether the liver ${ }^{54} \mathrm{Mn}$ values were expressed as a percentage of ${ }^{54} \mathrm{Mn}$ in whole liver or per unit liver, or as a percentage of carcass ${ }^{54} \mathrm{Mn}$ content. 
Table 6. Absorption of ${ }^{54} \mathrm{Mn}$ from human milk, bovine milk and infant formula by 13-d-old sucking rats 3 h after gastric intubation

(Mean values and standard deviations for sixteen, twenty-three and fifteen pups in bovine milk, human milk and infant formula groups respectively. Results of six to ten individual feeding experiments were pooled together for each of the three milk diets)

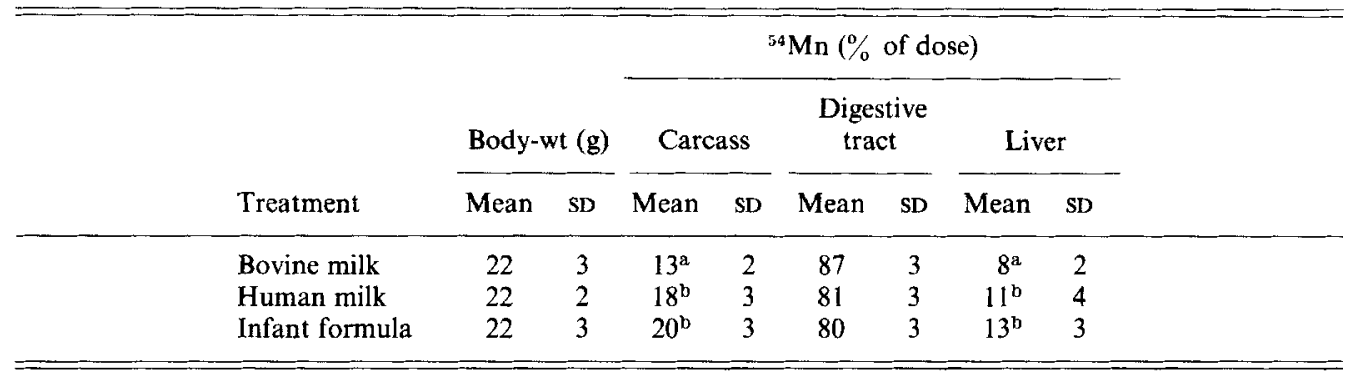

a, b Values with the same superscript letters were not significantly different $(P>0.05)$.

No difference in ${ }^{54} \mathrm{Mn}$ absorption was observed when 8-, 9-, 10- and 11-d-old rats were given human milk, bovine milk or infant formula even though the total amount of ${ }^{54} \mathrm{Mn}$ absorption and incorporation into the liver decreased with age (Fig. 1). However, not only was a smaller quantity of ${ }^{54} \mathrm{Mn}$ absorbed by 13 -d-old rats from the three milk diets but the availability of ${ }^{54} \mathrm{Mn}$ from bovine milk was significantly $(P<0.05)$ lower than that from the other two types of milk diet (human milk and infant formula). The results from the present study (Table 6) indicate that the uptake of ${ }^{54} \mathrm{Mn}$ into both carcass and liver was significantly higher $(P<0.05)$ in 13 -d-old pups given human milk or infant formula than in those given bovine milk. No difference in ${ }^{54} \mathrm{Mn}$ absorption was observed between 13-d-old rats given human milk or milk formula.

The validity of the use of sucking rats as a model for ${ }^{54} \mathrm{Mn}$ absorption from human-infant diets was tested by conducting a parallel feeding experiment in which 9 - or 10-d-old rats were given either rat milk or infant formula (both labelled extrinsically with ${ }^{54} \mathrm{Mn}$ ). The absorption of ${ }^{54} \mathrm{Mn}$ by 9 -d-old pups was 28 (SD 4) and 31 (SD 7) \% from rat milk and infant formula respectively. Incorporation of ${ }^{54} \mathrm{Mn}$ into the liver of the rats was 18 (SD 3) and 19 (SD 4$) \%$ of the dose from rat milk and infant formula respectively. These results indicate that no species specificity existed for ${ }^{54} \mathrm{Mn}$ absorption from rat milk.

The amount of ${ }^{54} \mathrm{Mn}$ absorbed by 10-d-old rats from infant formula at the end of $3 \mathrm{~h}$ of assimilation was 20 (SD 4) \% of the dose if they were fasted $10 \mathrm{~h}$ before feeding. This amount decreased to 16 (SD 5) \% if the rats were fasted for $18 \mathrm{~h}$ before feeding. ${ }^{54} \mathrm{Mn}$ absorption from infant formula by 11 - and 13-d-old pups was not affected by a longer period of fasting (18 h). However, ${ }^{54} \mathrm{Mn}$ absorption decreased in 8- to 13-d-old rats if fasted for less than $10 \mathrm{~h}$. Using infant rats of various ages, it was found that $12-14 \mathrm{~h}$ of fasting was an optimum time for 8- to 13-d-old rats. Similar results were obtained when human milk, bovine milk or rat milk were used.

\section{DISCUSSION}

There was no difference in ${ }^{54} \mathrm{Mn}$ availability from human milk, bovine milk and infant formula in 8- to 11-d-old rats. The difference observed in 13-d-old pups might be related to the stage of intestinal maturation. Developmental changes in the occurrence of an intestinal $\mathrm{Zn}$-binding ligand in rats have been shown previously (Duncan \& Hurley, 1978). 
Intestinal maturation may be dependent on the age as well as the rate of growth. Mn ligands, which may be found in the intestinal mucosa of older rats, probably selectively accept $\mathrm{Mn}$ from various ligands in the different types of milk. Our previous findings (Chan et al. 1984) in which ${ }^{54} \mathrm{Mn}$ absorption from human milk was less than that from bovine milk and infant formula differ from those of the present study in many respects. In our previous investigation the transport of ${ }^{54} \mathrm{Mn}$ was studied by the everted intestinal sac from adult rats using delipidized milk. The absorption was restricted to $1 \mathrm{~h}$ in a small section of jejunum. In the present work, ${ }^{54} \mathrm{Mn}$ absorption was studied in sucking rats (in vivo) using whole raw milk as ${ }^{54} \mathrm{Mn}$ carrier. A much higher quantity of ${ }^{54} \mathrm{Mn}$ was found in duodenal tissues of 10 -d-old or younger rats than in the jejunum or ileum of rats of the same age group.

In addition to studies comparing human milk, bovine milk and infant formula, we also used rat milk to determine if any species specificity existed for Mn absorption. No species specificity was observed in 9 - to 10 -d-old sucking rats.

It was suspected that the higher concentration of endogenous $\mathrm{Mn}$ in infant formula or rat milk as compared with human or bovine milk might compete with the transport of added ${ }^{54} \mathrm{Mn}$ during assimilation. However, when the non-radioactive $\mathrm{Mn}$ contents of human and bovine milk were increased to that in infant formula $(70 \mu \mathrm{g} / 1)$ or rat milk $(150 \mu \mathrm{g} / \mathrm{l})$ by adding $\mathrm{MnCl}_{2}$, no difference in ${ }^{54} \mathrm{Mn}$ absorption was observed between the $\mathrm{Mn}$-fortified and non-fortified milk samples. Because of the low levels of $\mathrm{Mn}$ in the milk diets used, it is unlikely that any competition occurred. Raw bovine milk was used instead of pasteurized milk to preserve the Mn-binding ligands in their natural form.

The ${ }^{54} \mathrm{Mn}$ activity of the digestive tract was measured without flushing out the lumen contents. When the ${ }^{54} \mathrm{Mn}$ activity of the small and large intestines was measured separately before flushing out lumen contents at the end of $3 \mathrm{~h}$ of feeding, more than $90 \%$ of intestinal ${ }^{54} \mathrm{Mn}$ was present in the small intestine. Flushing out the lumen contents with adequate amounts of saline ( $9 \mathrm{~g}$ sodium chloride/l) lowered the activity of the small intestine ${ }^{54} \mathrm{Mn}$ to less than $50 \%$ of the pre-washed values. However, subsequent washings caused further decrease in ${ }^{54} \mathrm{Mn}$ activity of the small intestine, probably due to the loss of mucosal cells or adsorbed ${ }^{54} \mathrm{Mn}$.

The content of trace elements in target organs or tissues and the associated activity and concentration of biochemically-active molecules, such as enzymes, are more frequently measured in trace element availability studies than their incorporation into the intestinal cells. For example, Fe availability is determined by measurement of haemoglobin content (Miller \& McNeal, 1983), while selenium availability is assessed by measurement of glutathione peroxidase (EC 1.11.1.9) activity (Alexander et al. 1983). In determining the availability of $\mathrm{Mn}$ in the present study, we considered the measurement of liver ${ }^{54} \mathrm{Mn}$ activity (and ${ }^{54} \mathrm{Mn}$ activity of the carcass minus digestive tract) to be more accurate and of greater significance than the ${ }^{54} \mathrm{Mn}$ content of intestinal tissue. It is not known at this time whether intestinal ${ }^{54} \mathrm{Mn}$ is re-excreted into the lumen or whether part of the intestinal ${ }^{54} \mathrm{Mn}$ is tightly adsorbed and cannot be flushed out easily without losing some mucosal cells. Up to $65 \%$ of absorbed ${ }^{54} \mathrm{Mn}$ was incorporated into the liver as shown in the present study. Thus liver can be used as a target organ for the study of Mn availability. Previously, Cotzias \& Papavasiliou (1964) and Papavasiliou et al. (1966) have shown that the liver regulates Mn homeostasis, while Black et al. (1984) have reported a linear increase in liver $\mathrm{Mn}$ in an availability study of $\mathrm{Mn}$ in chickens. Because of the variation of total liver weight of individual pups, the liver ${ }^{54} \mathrm{Mn}$ content was also expressed per $\mathrm{g}$ of liver. However, the values in Table 3 show that no difference in ${ }^{54} \mathrm{Mn}$ incorporation into liver existed among various milk diets regardless of whether liver ${ }^{54} \mathrm{Mn}$ was expressed in whole liver or per $\mathrm{g}$ of liver.

The lower availability of ${ }^{54} \mathrm{Mn}$ in bovine milk compared with human milk may not be due to the higher $\mathrm{Ca}$ and $\mathrm{P}$ contents of bovine milk since the $\mathrm{Ca}$ and $\mathrm{P}$ concentrations in 
the infant formula used in the present study were also higher than those of human milk (Committee on Nutrition, 1979). Bovine milk has a six to ten times higher concentration of casein than human milk (Miller \& McNeal, 1983). The effect of the high-casein content of the bovine milk on the decreased absorption of Mn could not be ruled out.

Both the existence and importance of $\mathrm{Mn}$-binding ligands in the absorption of this metal have been shown by various investigators. Previous bovine milk feeding to 5 -week-old rats resulted in increased subsequent $\mathrm{Mn}$ absorption when compared with previous feeding of a regular diet (Gruden, 1976). The use of ligands such as citrate or histidine increased $\mathrm{Mn}$ absorption in intestinal perfusates of rats (Garcia-Aranda et al. 1983). Citrate, however, may not be one of the main ligands to facilitate $\mathrm{Mn}$ absorption. It has been shown that bovine milk has a higher citrate content than human milk or infant formula (Sandström et al. 1983 a) but our studies show that ${ }^{54} \mathrm{Mn}$ absorption from bovine milk was lower than that from human milk or infant formula.

The use of ${ }^{54} \mathrm{Mn}$ is the method of choice in the present availability study since intrinsic milk Mn (especially of human milk) is very low. Extrinsic labelling has been used widely for availability studies of other trace elements. Duncan \& Hurley (1978) studied ${ }^{65} \mathrm{Zn}$ absorption in vitro from extrinsically labelled human milk, bovine milk and rat milk. Sandström et al. (1983a,b), using milks and formulas extrinsically labelled with ${ }^{65} \mathrm{Zn}$, determined its availability in rats. The absorption of ${ }^{115 \mathrm{~m}} \mathrm{Cd},{ }^{203} \mathrm{Hg}$ and ${ }^{54} \mathrm{Mn}$ has been determined (Kostial et al. 1980) in vivo from extrinsically labelled bovine milk. Egg yolk (Miller \& McNeal, 1983) and whole wheat flour (Fairweather-Tait \& Wright, 1984) have been extrinsically labelled with ${ }^{59} \mathrm{Fe}$ to determine $\mathrm{Fe}$ availability in rats.

At present the minimum daily requirement for $\mathrm{Mn}$ in human infants is not known. However, no deficiency of $\mathrm{Mn}$ has been reported in breast-fed infants. The present study shows that ${ }^{54} \mathrm{Mn}$ absorption from an infant formula and human milk is similar when sucking rats are used as a model. Absorption of $\mathrm{Mn}$ decreases with increasing age of animals. Supplementation of infant formula with excessive amounts of Mn could lead to Mn toxicity in human infants, which might be mild enough not to be expressed initially. However, one should not neglect the subtle changes that may be brought about by chronic or mild $\mathrm{Mn}$ intoxication. The animal model used in the present study is a logical approach to studying $\mathrm{Mn}$ absorption in human infants. We therefore believe that supplementation of infant formulas with higher quantities of $\mathrm{Mn}$ than is present in human milk may not be necessary. Future studies of Mn availability as affected by specific Mn-binding milk protein or ligands may be logical in order to identify biologically effective additives for infant formulas. The effect of age on Mn absorption from various milk diets also needs further investigation.

The authors would like to thank Dr A. Nunnery for his help with the computer analysis of the data and the mothers of the La Leche League of Oklahoma City for generously providing us with the milk used in the present studies. The study was supported by NIH Research Grant HD 16730.

\section{REFERENCES}

Alexander, A. R., Whanger, P. D. \& Miller, L. T. (1983). Journal of Nutrition 113, 196-204.

Barness, L. A. (1981). In Textbook of Pediatric Nutrition, pp. 21-28 [R. M. Suskind, editor]. New York: Raven Press.

Black, J. R., Ammerman, C. B., Henry, P. R. \& Miles, R. D. (1984). Nutrition Reports International 29, 807-814. Chan, W. Y., Bates, J. M. Jr. \& Rennert, O. M. (1982). Journal of Nutrition 112, 642-651.

Chan, W. Y., Bates, J. M. Jr., Rennert, O. M. Mahmood, A. \& Torres-Pinedo, R. (1984). Life Sciences 35 , 2415-2419.

Committee on Nutrition (1979). Pediatric Nutrition Handbook, p. 92. Evanston, IL: American Academy of Pediatricians. 
Cotzias, G. C. \& Papavasiliou, P. S. (1964). Nature 201, 828-829.

Duncan, J.R \& Hurley, L. S. (1978). American Journal of Physiology 235, E556-E559.

Fairweather-Tait, S. J. \& Wright, A. J. (1984). British Journal of Nutrition 51, 185-191.

Feller, W. F. \& Boretos, J. (1967). Journal of National Cancer Institute 38, 11-15.

Forbes, R. M. \& Erdman, J. W. Jr. (1983). Annual Review of Nutrition 3, 213-231.

Garcia-Aranda, J.A., Wapnir, R. A. \& Lifshitz, F. (1983). Journal of Nutrition 113, 2601-2607.

Gruden, N. (1976). Nutrition Reports International 14, 515-520.

Hoffman, F. A., Sawatzki, G., Schmitt, H. \& Kubanet, B. (1982). Laboratory Animal Science 32, 387-388.

Hurley, L. S. (1982). In Clinical, Biochemical and Nutritional Aspects of Trace Elements, pp. 369-378 [A. S. Prasad, editor]. New York: Alan R. Liss Inc.

Jackson, M. J., Jones, D. A. \& Edwards, R. H. T. (1981). British Journal of Nutrition 46, $15-27$.

Kostial, K., Robar, I., Blanusa, M. \& Landeka, M. (1979). Proceedings of the Nutrition Society 38, $251-256$.

Kostial, K., Robar, I., Blanusa, M. \& Simonovic, I. (1980). Environmental Research 22, 40-45.

McMillan, J. A., Oski, F. A., Lourie, G., Tomarelli, R. M. \& Landaw, S. A. (1977). Pediatrics 60, 896-900.

Miller, J. \& McNeal, L. S. (1983). Journal of Nutrition 113, 115-123.

Mraz, F. R. \& Eisele, G. R. (1977). Pediatric Research 69, 591-593.

Nagasawa, H. (1979). Laboratory Animal Science 29, 633-635.

Papavasiliou, P. S., Miller, S. T. \& Cotzias, G. C. (1966). American Journal of Physiology 211, 211-216.

Saarinen, U. M., Simes, M. A. \& Dallman, P. R. (1977). Journal of Pediatrics 41, 36-39.

Sandström, B., Cederblad, A. \& Lönnerdal, B. (1983a). American Journal of Diseases of Children 137, 726-729.

Sandström, B., Keen, C. L. \& Lönnerdal, B. (1983 b). American Journal of Clinical Nutrition 38, 420-428.

Sasser, L. B. \& Jarboe, G. E. (1977). Toxicology and Applied Pharmacology 41, 423-431.

Shah, B. G. (1981). Progress in Clinical and Biological Research 77, 199-208.

Shaw, J. C. L. (1980). American Journal of Diseases of Children 134, 74-87. 